\title{
The Empirical Analysis of Agricultural Mechanization \& Agricultural Production Efficiency and Farmers' Income Growth
}

\author{
Weiwei Guo ${ }^{1, a}$ \\ ${ }^{1}$ Gansu province, Qingyang city, China \\ a Email:gww2008ok@126.com
}

Keywords: Agricultural Mechanization; Unit Root Test; Granger Causality Test

\begin{abstract}
To analyze the influence of agricultural mechanization for farmers in the agricultural economy growth and contribution degree of farmers' income, according to the related data of national bureau of statistics from 2000 to 2012 farmers agricultural mechanization investment, the paper carries on the empirical research the farmers of agricultural mechanization investment shadow of agricultural efficiency and farmers' income and so on. Granger causality test and regression analysis shows the agricultural mechanization plays an important role in increasing per capital income of farmers, agricultural machinery investment per acre yield, agricultural output value, per capital grain output, etc,Finally, the article put forward to increase agricultural mechanization investment policies and recommendations.
\end{abstract}

\section{Introduction}

The agriculture is the weak industry of "four modernizations synchronous", the countryside is the vulnerable spot of comprehensive construction well-off society. since 2004 the central file no. 1 are concerned about the problem of "agriculture, rural and farmers" 11 times in succession, which is defined as the core topic of the economic growth 、 agricultural efficiency 、 increasing farmers income 、 improving the agricultural comprehensive production capacity deepening the rural reform and accelerating agricultural modernization. In 2013 \& 2014, for two consecutive years, the no. 1 files began to pay close attention to agricultural scale, encourage and support the contract for the managerial right to professional investors, family farms, agricultural cooperatives, and support the development of new type of agricultural management entity, encourage the development of farmers' professional co-operatives, direct funds to invest professional cooperatives. All these new rural policy provides policy support that is put forward to achieve the above goals, which indicate the direction of agricultural and rural development.

\section{The significance of agricultural mechanization}

As an important symbol of agricultural modernization, agricultural mechanization is referred to the use of advanced and applicable agricultural machinery and equipment improve the conditions of agricultural production and operation; constantly improve the level of agricultural production technology and the process of economic benefits, ecological benefits. It is regarded as directional strategic task to develop agricultural mechanization for the construction of modern agriculture, the important support to promote the agriculture modernization, and ensure the stable increase in grain production, increase farmers' income.

\section{(1) Agricultural mechanization is the only impassable way to realize agricultural modernization.}

The experience of developed countries shows that agricultural mechanization is the premise to realize agricultural modernization. To transform the mode of agricultural development and to realize agricultural modernization, the fundamental is to realize the mechanization of agriculture technology integration, labor process and production management informatization. Agricultural modernization in the aspect of technology is the modern agricultural machinery technology and biological technology equipment, setting up modern agricultural science and technology system, it 
is the important role of pervasive application in the field of agricultural production, fundamental changes by agricultural machinery, it also plays an important role in altering the backward mode of production, improving agricultural labor productivity, resource utilization, land productivity and implementing three "liberation". Namely the farmers can be free from the land, change the situation that people survive at the mercy of the forces of nature; The agriculture can liberate from the traditional mode of production, completely change the backward and inefficient production mode relying on human \& animal; The farmers will be free from the high strength work, completely change his life way of the face upwards toward the loess back, cultivates sunrise, rests sunset.

(2) It plays a role of the support and carrier of agricultural mechanization in promoting the stable increase of grain production.

Agricultural machinery undoubtedly greatly improves the labor productivity, breaks through the person and animal capacity, production efficiency limit, achieves the target of the modern agricultural technical requirements that the humanity cannot reach. Agricultural machinery also can achieve the target of reclaiming wasteland and transforming the middle-and-low-yielding fields, resisting natural disasters, delicacy sowing and field management, reducing the grain loss, promoting modern agricultural technology etc. moreover, ensuring agricultural sustainable growth. Grain production in China for the first time in half a century "nine", even a record high, total agricultural mechanization plays an irreplaceable important role. So to speak, the development of modern agricultural science and technology, the application of science and technology cannot do without the farm machinery. The main way of realizing the modern precision work and a large-scale application of advanced agricultural science and technology is to develop agricultural mechanization, to transform traditional agriculture with modern science and technology, to equip agriculture with modern material conditions,

\section{(3) Agricultural mechanization plays the alternative and promoting roles in sustained increase of rural incomes.}

Agricultural machinery is not only advanced production tools, also means of peasants to get rich. Agricultural mechanization development is closely related to rural labor transfer, increase farmers' income. By the development of agricultural mechanization, it is can greatly reduce the agricultural production cost, create wealth directly. The important reason of Agricultural products in international competition at a disadvantage is the cost is too high in our country.

Executing mechanical operation can increase crop yield, improve the quality of agricultural products, also save factors of production inputs, such as seeds, water, and fertilizer, reduce production cost, reduce cost and increase efficiency of agriculture. It is can promote stable rural labor transfer; widen the channel of the farmers' income. Analysis of historical statistics, as you can see, the per capital salary income of farmers per capital net income of rural households, from $31 \%$ in 2000 to gradually increase the proportion reached $44 \%$ in 2012 ; In spite of an increase in total, the proportion of per capital net income of farmers was be in the obvious downward trend, fell $23.3 \%$ in 2000 to $13.0 \%$ in 2012 . So, $2000-2012$ per capital net income of rural residents to maintain the growth rate of nearly $20 \%$, there are quite a part to agricultural mechanization which has greatly raised Labor productivity, save labor time, guarantee the short time efficiently to complete the agricultural production, replaced the rural labor force and for a large number of rural labor force migrant workers provide strong support.

\section{The model and data}

For the analysis influence farmers for agricultural mechanization in the agricultural economy growth and contribution degree of farmers' income, this article counted seven important variables, including worth of agricultural mechanization total power (Y), per capital net income of farmers (X1), the cultivated land (X2) per acre yields (X3), agricultural output value per capital (X4), worth of fiscal funds for supporting agriculture (X5) and per capital grain yield (X6). Among them, worth of agricultural machinery total power is expressed as the ratio of the total power of agricultural mechanization to the farmer's country and number; cultivated land area and cultivated land is expressed as the ratio of the primary industry employment; Per acre yields is expressed agricultural 
output to the ploughed field; Per capital agricultural output value is expressed as the agricultural output value and the ratio of the rural households; per rural households financial supporting agriculture budget is defined as the agriculture, forestry \& water to rural households; the rest of the data are in accordance with the national bureau of statistics web site shall prevail.

\section{The empirical analysis}

For the analysis of the various indicators, the relationship between different variables of the need to use the appropriate data model fitting, linear or nonlinear relationship between the commonly used method is to set up multiple linear regression, and for part of the nonlinear relationship between variables, or polynomial transformation by logarithmic transformation, index transformation, in order to find out the most representative rule between each variable, for the future of the prediction and control to provide a more scientific basis.

Stability analysis. For time series data, to avoid "false return", the existing various statistical indexes stationary test is necessary. Analyzing the various statistical indicators raw data, first order difference analysis, all variables are non-stationary series. Observing the second order difference, agricultural machinery total power and per capital grain yield is under the $5 \%$ level significantly, other variables are significant under $1 \%$ level steadily sequence, which ruled out the possibility of spurious regression, the results are shown in table 1.

Table 1 the variables of second-order differential stationary test results

\begin{tabular}{|c|c|c|c|c|c|}
\hline variable & ADF statistics & $1 \%$ critical value & $5 \%$ critical value & $10 \%$ critical value & conclusion \\
\hline Y & -3.869187 & -4.297073 & -3.212696 & -2.747676 & steady * \\
\hline X1 & -6.123601 & -4.420595 & -3.259808 & -2.771129 & steady \\
\hline X2 & -4.384809 & -4.297073 & -3.212696 & -2.747676 & steady \\
\hline X3 & -6.092515 & -4.420595 & -3.259808 & -2.771129 & steady \\
\hline X4 & -11.32914 & -4.582648 & -3.320969 & -2.801384 & steady \\
\hline X5 & -5.5198 & -4.803492 & -3.403313 & -2.841819 & steady \\
\hline X6 & -4.285407 & -4.582648 & -3.320969 & -2.801384 & steady * \\
\hline
\end{tabular}

Note: * represents the significant under $5 \%$ level.

The granger causality test. Granger causality test assumes that the two variables $\mathrm{X}$ and $\mathrm{Y}$ under the condition of contains information about the past, if the variable $\mathrm{X}$ can better explain the future changes of the variable $\mathrm{Y}$, and the interpretation is better than single by the past information to the prediction effect of $\mathrm{Y}, \mathrm{Y}$ is considered variable $\mathrm{X}$ is the granger cause of variable $\mathrm{Y}$. The test the hypothesis that there is no causality, namely when $\mathrm{F}$ statistics and their probability value significantly, which denied the original hypothesis. According to this principle, in the case of two phase lag, agricultural machinery investment related statistical variables granger causality test results such as table 2 .

Table 2 agricultural machinery investment related statistical variables granger causality test

\begin{tabular}{|c|c|c|c|}
\hline null hypothesis & statistics & F statistics & probability \\
\hline X6 does not Granger Cause Y & \multirow{2}{*}{11} & 0.86122 & 0.469 \\
\hline $\mathrm{Y}$ does not Granger Cause X6 & & 4.73447 & $0.0584 *$ \\
\hline X5 does not Granger Cause Y & \multirow{2}{*}{8} & 0.6385 & 0.5875 \\
\hline $\mathrm{Y}$ does not Granger Cause X5 & & 7.66242 & $0.0662 *$ \\
\hline $\mathrm{X} 4$ does not Granger Cause $\mathrm{Y}$ & \multirow{2}{*}{11} & 1.94472 & 0.2233 \\
\hline Y does not Granger Cause X4 & & 49.7714 & $0.0002 * * *$ \\
\hline X3 does not Granger Cause Y & \multirow{2}{*}{11} & 1.34431 & 0.3293 \\
\hline Y does not Granger Cause X3 & & 20.8152 & $0.0020 * * *$ \\
\hline $\mathrm{X} 2$ does not Granger Cause $\mathrm{Y}$ & \multirow{2}{*}{11} & 0.27806 & 0.7665 \\
\hline $\mathrm{Y}$ does not Granger Cause $\mathrm{X} 2$ & & 3.63271 & $0.0925^{*}$ \\
\hline $\mathrm{X} 1$ does not Granger Cause $\mathrm{Y}$ & \multirow{2}{*}{11} & 4.80811 & $0.0567 *$ \\
\hline Y does not Granger Cause X1 & & 7.33342 & $0.0245 * *$ \\
\hline
\end{tabular}

Note: $*$ indicates the $10 \%$ significant level, $* *$ said the $5 \%$ significant level, $* * *$ said the $1 \%$ significant level. 
From the point of inspection results, if sorting according to the significance level, worth of agricultural machinery investment motivation, in turn, is the agricultural output value, per acre per capital income, per capital grain yield, the cultivated land per worth of fiscal funds for supporting agriculture, the granger cause of per capital net income of farmers and worth of agricultural machinery investment incentives are granger causality.

The model design and empirical analysis. Based on the above understanding, according to Cob-Douglas production function , on the basis of the natural logarithm (base e) of each variable, in order to further reveal worth of agricultural machinery dynamic investment of per capital net income of farmers, the farmland per acre yield, agricultural output value, per capital, per capital grain output worth of financial supporting agriculture budget contribution degree of fitting explanatory variables respectively after worth agricultural machinery investment dynamics in two cases of each is a function of explanatory variables. The results are shown in table 3.

Table 3 agricultural machinery investment analysis influence on agricultural efficiency

$\&$ increasing the income of farmers

\begin{tabular}{|l|l|l|l|l|l|}
\hline Explained variables coefficients & T statistics & F statistics & P value & $\mathrm{R}^{\wedge} 2$ & $\mathrm{DW}$ value \\
\hline LN(X1),2.39 & 62.60 & 3919.3 & 0 & 0.998 & 1.47 \\
\hline LN(X2),0.55 & 13.70 & 187.8 & 0 & 0.95 & 1.33 \\
\hline LN(X3),2.88 & 21.31 & 454.2 & 0 & 0.98 & 0.49 \\
\hline LN(X4),2.30 & 35.10 & 1231.8 & 0 & 0.99 & 2.29 \\
\hline LN(X5),5.17 & 25.65 & 658.0 & 0 & 0.99 & 2.04 \\
\hline LN(X6),0.46 & 10.34 & 107.0 & 0 & 0.92 & 2.54 \\
\hline
\end{tabular}

From the fitting $T$ statistic, the $F$ statistics, an affirmative coefficient $R \wedge 2$, agricultural machinery investment of the above are explained variables have significant impact. But when noting the DW values, the result of regression analysis and granger causality test results is fairly close, and suggest that agricultural machinery investment for per capital grain yield, agricultural output value, per capital worth of financial supporting agriculture budget influence more prominent, and the per capital net income of farmers has obvious effects, per capital cultivated land and earnings per acre is obviously autocorrelation.

In order to further verify the correctness of the regression, except the DW value, the regression equation tests the residual of $\mathrm{Q}$ statistic and residual error sequence correlation diagram, LM statistics test; the results found that earnings per acre of the regression equation of the agricultural machinery investment is obvious in the aspects of autocorrelation, the results are shown in table 4.

Table 4 Breusch-Godfrey Serial Correlation LM Test

\begin{tabular}{|l|r|l|r|}
\hline F-statistic & 3.431028 & Prob. F(2,7) & 0.0915 \\
\hline Obs*R-squared & 5.445268 & Prob. Chi-Square(2) & 0.0657 \\
\hline
\end{tabular}

According to the principle of LM test, the $\mathrm{P}$ value, if under the $10 \%$ significant level, the regression equation of the residual error there is no serial correlation, but if setting at $5 \%$ significant level, there is serial correlation. The equation of the residual sequence correlation diagram shows that there is a first order autocorrelation, need the original regression equation. The results are as follows.

$$
\begin{array}{ll}
\mathrm{LN}(\mathrm{X} 3)=1.43 * \mathrm{LN}(\mathrm{Y}(-2))+[\mathrm{AR}(1)=0.88] \\
\mathrm{T} \text { statistics } \quad 46.47 & 17.64
\end{array}
$$

$\mathrm{R}^{\wedge} 2=0.993$, adjusted $\mathrm{R}^{\wedge} 2=0.992, \mathrm{P}=0, \mathrm{DW}=2.11$

Conclusion and policy recommendations. Based on the analysis of the regression results, it can be seen that agricultural machinery investment has important effect to agricultural efficiency and farmers' income, unit 2.39 worth of agricultural machinery investment incentives for per capital net income of (X1), the cultivated land (X2) earnings per acre (X3), per capital agricultural output value (X4), 2.39 worth of fiscal funds for supporting agriculture (X5), per capital grain output (X6) contribution, in turn, is $¥ 2.39,0.55$ acre, $¥ 1.43$ and $¥ 2.30, ¥ 5.17$ and $0.46 \mathrm{~kg}$. Therefore, we should increase agricultural machinery investment through various channels, build in "government guide, farmers dominate, social participation" the diversification of agricultural mechanization investment system, realize the agricultural sustainable development and increasing farmers' income. (1) continue to implement the agricultural subsidy policy, increase the government 
fiscal spending to reduce the investment cost of farm agricultural mechanization, and actively explore and try more benefit agricultural inputs new policy; (2) guarantee the floor price policy for grain and increase farmers on grain yield and per capital income growth expectations, arouse the enthusiasm of farmers to plant and initiative of agricultural inputs; (3) actively explore to set up new agricultural management main body, and develop and perfect the mechanism of benefit of farmland moderate flow, improve the rural land intensive management system, achieve scale management to guide farmers to invest in agricultural mechanization.

\section{References}

[1] Pingjun He. The research on China's agricultural infrastructure supply efficiency. Cambridge university press, 2012:125-129

[2] Tiemei Gao. The econometric analysis method and the application and instance modeling Eviews application and instance, tsinghua university press, 2006:126-143

[3] Zhaoxiong Wu etc. Farmer's agricultural mechanization investment behavior research - in hubei province, for example, agricultural technology economy, 2013 (6): 56-62

[4] Futian Sun. The contribution of agricultural mechanization of agriculture development and equipment level of agricultural mechanization research, northeast agricultural university, Ph.D. Thesis, 2004): 72-74

[5] HongJie Bao, Deguang Liu, etc. The relationship between agricultural mechanization and agricultural economic growth empirically, statistics and decision, 2012 (21): 139-141 